\title{
Characteristics of Korean Forest Fires and Forest Fire Policies in the Joseon Dynasty Period (1392-1910) Derived From Historical Records
}

\author{
Donghyun Kim ${ }^{1,2} \mathbb{D}$ \\ 1 Department of Fire Safety Engineering, Jeonju University, Jeonju 55069, Korea; 72donghyunkim@jj.ac.kr; \\ Tel.: +82-63-220-2233 \\ 2 International Institute for Applied Systems Analysis (IIASA), A-2361 Laxenburg, Austria
}

Received: 18 October 2018; Accepted: 29 December 2018 ; Published: 4 January 2019

check for updates

\begin{abstract}
This study examined the records of forest fire outbreaks and characteristics over the 518 years of the Joseon Dynasty period (1392-1910) through the analysis of major historical records of Korea. The historical books used in this study were 14 major national historical books, and include the Annals of the Joseon Dynasty (朝鮮王朝實錄), the Diaries of the Royal Secretariat (承政院日記)， and the literature was examined, centering on official records of the royal palace in the Joseon Dynasty period. The contents of forest fires recorded in the historical record literature include the overviews of outbreak, forest fire types, and forest fire damage. According to the results of analysis of historical records, the largest forest fire damage was in the forest fire that occurred on the east coast in 1672, in which 65 persons died and in the forest fire that occurred in the same area in 1804, in which 61 persons died and 2600 private houses were destroyed by fire. The causes of fire outbreak were shown to be unknown causes in 42 cases, accidental fires in 10 cases, arson in 3 cases, thunder strike in 3 cases, hunting activities in 2 cases, child playing with fire in 1 case, cultivating activities in 1 case, and house fire in 1 case. Forest fire outbreaks were analyzed by region and by season and according to the results, $56 \%$ (39 cases) of the forest fires broke out on the east coast and $73 \%$ (46 cases) broke out in the spring. Forest fire policies include those for general forests, those for reserved forests, those for prohibited forests, those for capital city forests, those for royal family's graves, royal ancestral shrine, and placenta chamber, those for hunting grounds such as martial art teaching fields, and relief policies for people in areas damaged by forest fires, forest fire policies for national defense facilities such as beacon fire stations, and burning and burning control policies for pest control. In conclusion, due to the seriousness of forest fires in the Joseon Dynasty period, the royal authority and local administrative agencies made various forest fire prevention policies, policies for stabilization of the people's livelihood damaged due to forest fires, and methods to manage major facilities in forests.
\end{abstract}

Keywords: Joseon Dynasty period; historical records; forest fire; forest fire policies; forest fire record; the annals of the Joseon Dynasty

\section{Introduction}

Korea is climatically located in the mid-latitude temperate climatic zone, and has clear and dry weather characteristics in spring and autumn due to the effects of migratory anticyclones. As for forests, coniferous forest zones including pine forests, which are vulnerable to forest fires accounts for about $42 \%$ of the entire forests in Korea where forests account for $64 \%$ of the entire area of the territory. The topography of Korea shows irregular directivity because mountains are overlapping and crossing each other. The mountains have environments close to village life and high slopes with an average elevation of $450 \mathrm{~m}$ and an average gradient of $5.7^{\circ}$. Therefore, Korea is in environments vulnerable to the outbreak and spread of forest fires [1]. 
On reviewing the forest fire statistics over the last 10 years (2008-2017), it can be seen that 70\% of the forest fire damage occurred in spring when the atmosphere is dry and 480 forest fires broke out, causing damage to 1250 ha of forests per year on average. In the 21st century, massive forest fire damage occurred such as damage to 23,794 ha in a fire in the east coast area in 2000, damage to 3095 ha in a forest fire in Cheongyang/Yesan in, 2002, and damage to 974 ha in a forest fire in Yangyang in 2005, and loss of national treasury grade cultural properties due to fires [1].

At this time point where the risk of forest fires is increasing globally due to climate change and changes in human activities, this study was intended to analyze the time of outbreak of forest fires, regional characteristics, causes of forest fire outbreak, and responding policies based on the historical books that were written from 626 years ago from now, 1392 when the Joseon Dynasty period began been. In the previous research on the forest fire history, such as studies of Power et al. (2010) and Anderson et al. (2010), Gavin (2001), Huang et al. (2006) Julie C. Aleman et al. (2018) and Mark Hardiman et al. (2018) only focused on charcoal-based fire history [2-5]. Sarah H. Millspaugh et al. (2010) used the radiocarbon dates method to examine the frequency and weather changes of Yellowstone National Park over the last 1700 years [6]. Hessl et al. (2016) and Yao et al. (2017) studied fire history using fire scar chronologies $[7,8]$.

Fire history records in wildland have demonstrated that the fire regime, i.e., the frequency, season, and intensity of fires in a particular ecosystem [9], is largely controlled by climate variability and vegetation characteristics [10-14]. Past changes in biomass burning are documented for recent years through satellite observations, during the past several centuries by fire-scarred tree-ring records and during past millennia by sedimentary records of charred plant materials or charcoal found in lakes, bogs and other natural archives [2].

Fire history records by the Charcoal Database Analysis (CDA) have been useful to estimate broad-based fire records or the initial settlement time for a specific area in relation to mankind's use of fire [15].

Charcoal records have the advantage of time depth that is greater than that of the other types of observations, as well as a more global coverage than what is currently available with tree-ring fire records [2]. The Global Palaeofire Working Group (GPWG) was created in 2006 as fire history records developed and analysed with the use of the Global Charcoal Database (GCD) which furthered our understanding of the control of fire and the impact thereof in the Earth system on a wide range of spatial and temporal scales [16].

In the Korean and GPWG studies, the database for the Korean charcoal deposits has not been analysed yet. Hence, it is not feasible to compare results with those from the analysis of forest fire history records conducted for this study.

The historical books, recorded by the dynasty in the Joseon Dynasty period, were recognized for their accuracy and value to the extent that they were registered as UNESCO record cultural heritages. Therefore, this study was intended to analyze the characteristics of forest fires occurred in the Joseon Dynasty period and compare the results with the characteristics of forest fires occurred recently in order to understand the macroscopic behaviors of forest fires in Korea and analyze the forest fire prevention policies of the Joseon Dynasty with a view to gaining the wisdom to more fundamentally solve the problems faced in reality. This study analyzed matters related to forest fire policies based on the historical books of the Joseon Dynasty period. The years and dates used were changed according to the current solar calendar; provided that the years and dates in translations of original texts were written according to the lunar calendar. We also wanted to compare the characteristics of forest fires about 600 years ago. In this study, the title of the history record without the official English name is written in the sound pronunciation list. 


\section{Method}

\subsection{Study Area}

The scope of this study covers the entire Korean Peninsula, including South and North Korea. The Korean Peninsula is approximately $1100 \mathrm{~km}$ in length from south to north and approximately $300 \mathrm{~km}$ in width from east to west; the total area is approximately 220,000 km² [17]. Figure 1a was provided from the study for assessing climate change impact on forest habitat sustainability and diversity in the Korean Peninsula by Lim et al. [18]. The Korean Peninsula corresponds to the mid-latitude region (33-43 N) and is located in the east of the Asian continent; it belongs to the temperate monsoon climate, which is affected by seasonal winds [19]. It is characterized by climatic characteristics of hot, humid summers and cold, dry winters and dry and strong wind Spring-Autumn season. Modern vegetation of this area is occupied by temperate deciduous-broadleaf mixed forest, coniferous forest, broadleaf forest distributed and controlled by altitude within the landscape as shown in Figure $1 b$ [20].

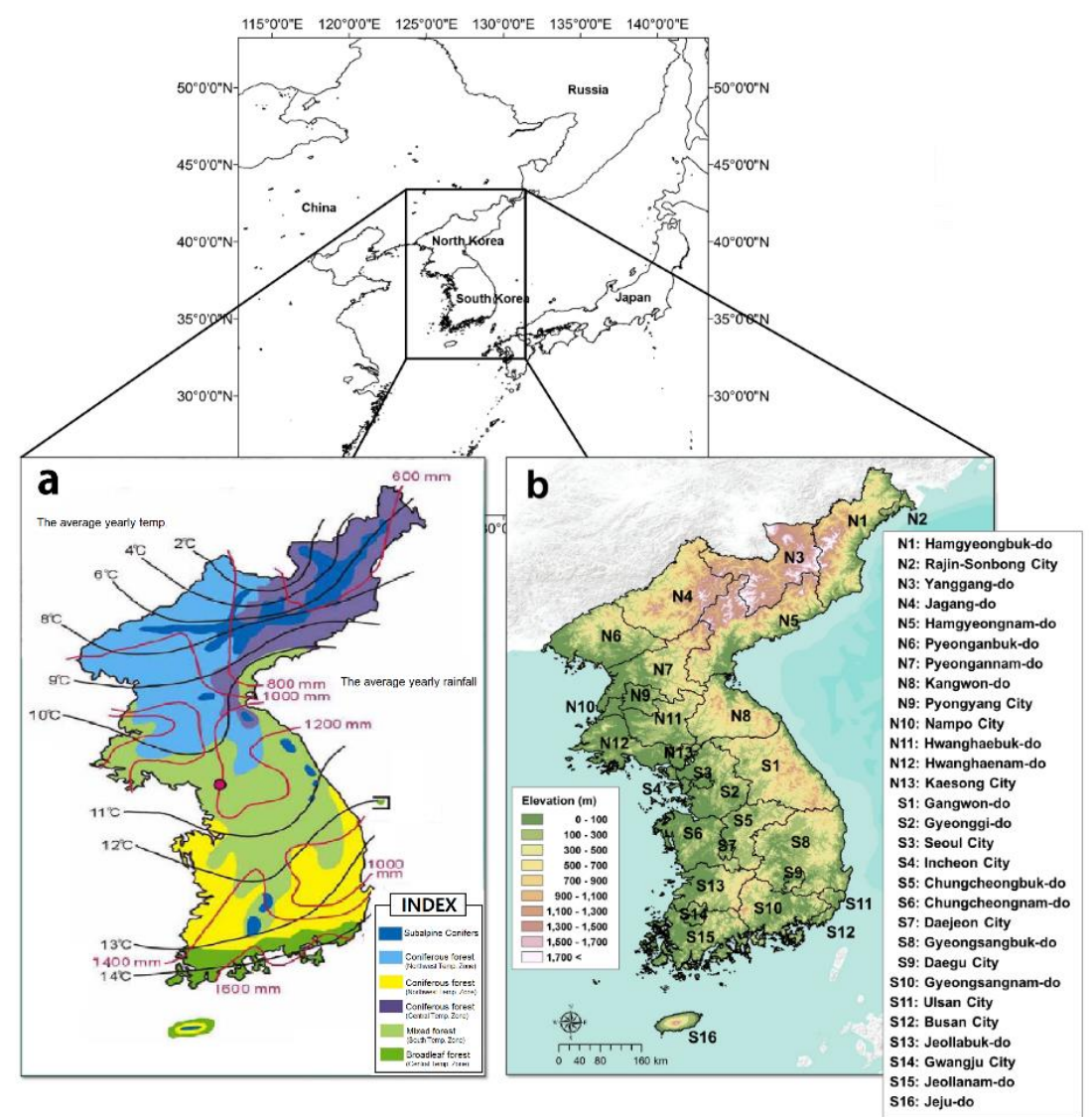

Figure 1. Study area (a): forest species, the average yearly temp. and rainfall [18], (b): administrative boundary with topographical information [20].

\subsection{Analysis Data}

The records of Joseon Dynasty forest fires were analyzed by using the following 14 history records 'the Annals of the Joseon Dynasty (朝鮮王朝實錄)', 'Sinbosugyijiprok (新補受教集錄)', 'Sugyojiprok (受教集錄)', 'Jedosongkumsamok (諸道松禁事目)', 'Archives from Records of the Border Defense Council (備邊司謄錄)', 'Gyeongguk daejeon (經國大典)', 'Goryeosa Jeolyo, Essentials of Goryeo history (高麗史節要)', 'Korean translation of Chungbomunheonbigo (國譯增補文獻備考)', ‘Kumjojeolmokimun (禁條節目移文)', 'Daejonhoetong (大典會通)', ‘Taezonsokrok (大典續錄)', 'Seungjeongwon Ilgi, the Diaries of the Royal Secretariat (承政院日記)', 
'Hwanghaedoyeonhaekumsongsamok (黄海道沿海禁松節目)', and 'the compilation of ministry proposals (各部聽議書存案)'.

A general overview of 14 historical records is as follows,

(1) Joseon wangjo sillok, or "the Annals of the Joseon Dynasty" (朝鮮王朝實錄): History record consisting of 1893 volumes bound in 888 books in which the history of the Joseon Dynasty over 519 years with 27 kings from the period of King Taejong's reign starting in 1392, the year of national foundation, to the period of King Soonjong's reign starting in 1910 is recorded in a chronological order from the date of the founding of the Joseon Dynasty in 1392, It is National Treasure No. 151 and was registered as a UNESCO World Heritage in 1997 [21,22].

(2) Sugyojiprok, or “King's Command Compilation” (受教集錄): Law books compiled in 1698 (24th year of King Sukjong's reign) by collecting diplomatic relations and ordinances given to each province and government offices consisting of six volumes bound in two books [23].

(3) Sinbosugyojiprok (新補受教集錄): Law books compiled by extracting only those laws that would be enforced out of the laws promulgated after the Sugyojiprok (受教集錄) in the late Joseon Dynasty period consisting of two volumes bound in two books [24].

(4) Jedosonggeumsamok (諸道松禁事目): A book delivered to the relevant government office in 1788 (12th year of Kingf Jeongjo's reign) containing instructions regarding the forest protection by supervisor and woodmen who watch the pine forests and pine fields in various regions [25].

(5) Bibyeonsa Deungrok, or “Archives from the Border Defense Council" (備邊司腠錄): Diary style records of the activities of the Border Defense Council, which was the highest-ranking national council in the mid-late Joseon Dynasty period, consisting of 273 books recorded from 1617 to 1892. Previous records have been lost due to Japanese invasion [26].

(6) Gyeongguk Daejeon, or "National Code" (經國大典): Second unified law book made by integrating the original copy of the Gyeongjeyukjeon (經濟六典), which is a law book in the early days of the foundation of Joseon, the sequel, and later laws [27].

(7) Goryeosa Jeoryo, or “Essentials of Goryeo history" (高麗史節要): Historical records of the Goryeo Dynasty before the Joseon Dynasty organized in chronological order consisting of a total of 35 volumes [28].

(8) Gukyeok Jeungbo munheonbigo or Korean translation of "the Revised and Enlarged Edition of the Comparative Review of Records and Documents" (增補文獻備考): Korean translation of books in which the orders of the King between 1903 and 1908 consisting of a total of 250 volumes [29].

(9) Gemmjojeolmokimun (禁條節目移文): Books in which the rules prohibiting various actions issued by the kings during the Joseon Dynasty period consisting of 14 volumes [25].

(10) Daejeonhoetong, or "Great Administrative Code" (大典會通): The final unified law book in the Joseon Dynasty in which various royal messages and ordinances over 80 years after the Daejeontongpyeon system in 1865 consisting of six volumes bound in five books [30].

(11) Daejeon songnok, or “Expansion of the Gyeongguk Daejeon" (大典續錄): Public law book compiled by collecting current laws and ordinances until 1491 after the enactment of Gyeonggukdaejeon consisting of six volumes bound in one book [31].

(12) Seungjeongwon Ilgi, or “the Diaries of the Royal Secretariat” (承政院日記): Diary style history records containing the documents and events handled every day by the Royal Secretariat, which was in charge of records regarding king's orders and the execution in the Joseon Dynasty period. Records from 1623 to 1894 exist, and the previous records were lost due to Japan's invasion [32]. 
(13) Hwanghaedo yeonhae geumsongsamok (黃海道沿海禁松節目): One of Jedosonggeuumsamok that provides management and regulations for the protection of pine forests in the Joseon Dynasty period. This is a special law for the protection and management of pine trees in coastal area of Hwanghaedo in 1684 [25].

(14) Gakbu cheonguiseo jonan, or “the compilation of ministry proposals" (各部聽議書存案): Compilation of official documents exchanged by Uijeongbu government office with various provincial government offices in 1899 in the Joseon Dynasty period [33].

\subsection{Analysis Method}

The analysis of 14 historical records used in this study is based on the DB data constructed by the Institute for the Translation of Korean Classics over the last 40 years. Some historical records and classics are still being translated and the periods of records not translated were written based on the data such as 'History of Forest Policies in the Late Joseon Dynasty Period' [34], 'History Outside the Joseon History' [35], and Daejeon songnok (大典續錄) (Ministry of Government Legislation, 1975). The agencies that were in charge of forest work in the Joseon Dynasty period and forest fire management systems were classified and the forest fire policies in the Joseon Dynasty period were classified by policy, times, period, and target. In particular, as for the classification by period, the periods were classified into the early Joseon (early days after national foundation 1392-1476), the mid Joseon (1477-1746), and the late Joseon (1747-1910) based on the completion of Gyeongguk daejeon (經國大典) (1476) and the sequel to Gyeongguk daejeon (1746), which were the foundation of the legal system in the Joseon Dynasty period [36]. In addition, data on the agencies in the field of forests and agencies in charge of forest fire management in the Joseon Dynasty period were also analyzed for the first time.

\section{Study Results}

\subsection{Forest and Forest Fire Managing Agencies}

Forest and Forest Fire Agency

When civil and military officials were organized after the foundation of Joseon Dynasty in 1392, forests were put under the control of Sajaegam (司宰監). Thereafter, in 1405, Joseon Dynasty divided administrative departments into six ministries; Ministry of Interior, Ministry of Finance, Ministry of Culture and Education, Ministry of National Defense, Ministry of Justice, and Ministry of Industries under Uijeongbu (議政府) and placed mountain and river officials under the Ministry of Industries, which was in charge of mountains and rivers (山澤), artisans (工匠), civil engineering (土木), building and repair (營繕), farms cultivated by stationary troops (屯田), salt fields (鹽場), potters and casting (陶治) to control works such as forest management and use [36,37].

In the Joseon Dynasty period, forest fire management was conducted by both military administrative organizations and the central and provincial administrative organizations and largely targeted at forests nationwide, but first targeted at four mountains ((四山), refer to Bukaksan, Inwangsan, Namsan, and Naksan, which were around the the Joseon Dynasty period capital city) around the capital city and targeted at other areas thereafter. Forest fire policies in the Joseon Dynasty period were carried out by the Ministry of National Defense, the Ministry of Industries, the Ministry of Culture and Education, and provincial government offices Table 1 [36,37]. Forest fire management in the central government units except for the local organizations was mostly carried out by the Ministry of National Defense and the Ministry of Industries and the central government established firewood storages (柴場), which are placed designated by the government for storage of firewood, in individual government offices to prohibit unauthorized logging and prevent forest fires [36,37]. 
Table 1. Government organization in charge of the forest management area

\begin{tabular}{ll}
\hline $\begin{array}{l}\text { Organization } \\
\text { (Korean Name) }\end{array}$ & Region of Forest Fire Prevention \\
\hline Ministry of National Defense (Byeongjo) & $\begin{array}{l}\text { Mountains in the capital city Hanyang, mountains within 4km from } \\
\text { the castle, areas around royal tombs, general mountains in Provinces, } \\
\text { forests around beacon mounds, pine fields, reserved mountains, } \\
\text { prohibited mountains, and forests for national defense }\end{array}$ \\
\hline Ministry of Industrial (Gongjo) & $\begin{array}{l}\text { Mountains in the capital city Hanyang, mountains within } 4 \mathrm{~km} \text { from } \\
\text { the castle, mountains around the royal palace }\end{array}$ \\
\hline Ministry of Culture and Education (Yejo) & Areas around royal tombs \\
\hline Local government & $\begin{array}{l}\text { general mountains in Provinces, reserved mountains, prohibited } \\
\text { mountains, areas around Buddhist temples }\end{array}$ \\
\hline Government office & Firewood storage \\
\hline Temple & Areas around Buddhist temples and archives \\
\hline Chunchugwan & Areas around archives \\
\hline
\end{tabular}

\subsection{Forest fire characteristics}

A total of 63 forest fire outbreaks and a total of 108 forest fire policies were recorded in historical books in the Joseon Dynasty period as shown in Table 2. On reviewing the number of forest fires occurred by reign of king, it can be seen that the largest number of fires occurred in the reign of Hyeonjong (14) followed by Sukjong (13), Jeongjo, Sunjo (7), Jungjong (5), Sejong, Injo, Cheoljong (3), Seongjong, Yeongjo (2), Taejong, Myeongjong, Gyeongjong, Gojong (1) as shown in Figure 2. Where, the largest number of forest fires as 7 was recorded in the 4th year of the reign of Sunjo (1804) followed by a year in the reign of Sukjong, Hyeonjong, Jungjong, Jeongjo, Sejong/Seongjong/Injo, Taejong/Myeongjong/Gyeongjong/Sunjo/, Cheoljong in order of precedence.

Table 2. References of the Joseon Dynasty historical record books examined in this study

\begin{tabular}{|c|c|c|}
\hline Record Books & $\begin{array}{c}\text { Number of Forest } \\
\text { Fire Records }\end{array}$ & $\begin{array}{c}\text { Number of Forest } \\
\text { Fire Policy }\end{array}$ \\
\hline Joseon wangjo sillok, or “the Annals of the Joseon Dynasty” (朝鮮王朝實錄) & 42 & $78(82) *$ \\
\hline Sugyojiprok, or “King's Command Compilation” (受教集錄) & - & 3 \\
\hline Sinbosugyojiprok (新補受教集錄) & - & 9 \\
\hline Jedosonggeumsamok (諸道松禁事目) & - & 3 \\
\hline Bibyeonsa Deungrok, or “Archives from the Border Defense Council” (備邊司謄錄) & 7 & 2 \\
\hline Gyeongguk Daejeon, or “National Code” (經國大典) & - & 1 \\
\hline Goryeosa Jeoryo, or “Essentials of Goryeo history” (高麗史節要) & - & 2 \\
\hline $\begin{array}{l}\text { Gukyeok Jeungbo munheonbigo or Korean translation of "the Revised and Enlarged Edition } \\
\text { of the Comparative Review of Records and Documents" (增補文獻備考) }\end{array}$ & - & 1 \\
\hline Gemmjojeolmokimun (禁條節目移文) & - & 1 \\
\hline Daejeonhoetong, or “Great Administrative Code" (大典會通) & - & 1 \\
\hline Daejeon songnok, or “Expansion of the Gyeongguk Daejeon” (大典續錄) & - & 1 \\
\hline Seungjeongwon Ilgi, "the Diaries of the Royal Secretariat" (承政院日記) & 13 & 1 \\
\hline Hwanghaedo yeonhae geumsongsamok (黃海道沿海禁松節目) & - & 1 \\
\hline Gakbu cheonguiseo jonan, or “the compilation of ministry proposals” (各部聽議書存案) & 1 & - \\
\hline Total & 63 & $104(108) *$ \\
\hline
\end{tabular}

Note * the figure in parentheses refers to the number of policies with duplicated policies included. 


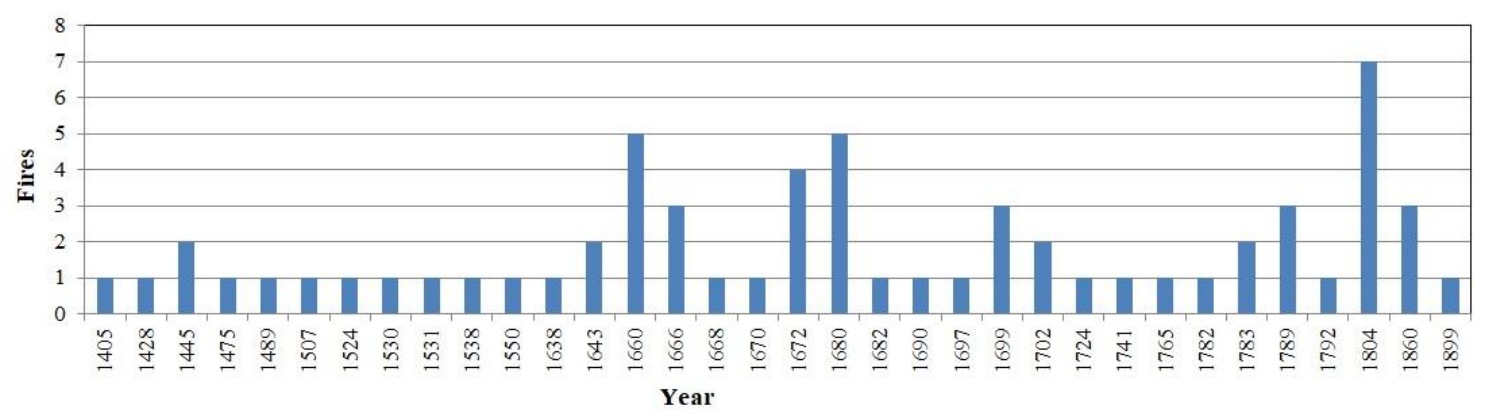

Figure 2. Forest fires in Joseon Dynasty.

\subsubsection{By Cause}

On reviewing the causes of forest fire outbreak in Figure 3, it can be seen that, of the 63 cases in total, 42 cases, the larger number, had no clear cause recorded and 10 cases occurred due to mistake. Forest fires due to arson and those due to thunder stroke in summer were recorded in three cases respectively, two cases where the military set fire for hunting were recorded, and each of forest fires due to each of child playing with fire, burning the ridge between rice paddies or fields, and house fire was recorded in one case, respectively. As shown in Figure 3, there is a record of arson causes of fire in historical records. In this record, it is recorded that there are three cases including deliberate arson, curiosity arson, and social complaints which were not able to work the government post.

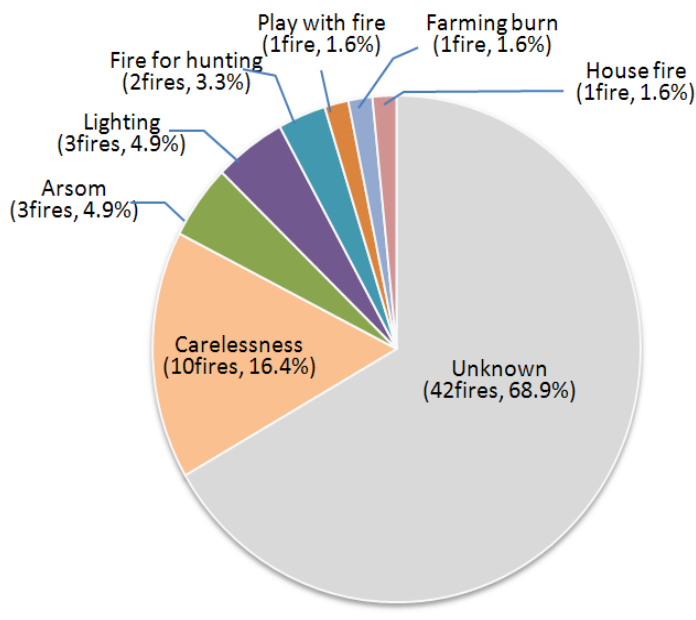

Figure 3. Causes of forest fires in Joseon Dynasty.

\subsubsection{By Periods}

In the records of forest fires in the Joseon Dynasty period, the exact date of the forest fire outbreaks was recorded in only 19 out of the total 63 cases. Therefore, the analysis data are different from the actual forest fire outbreak dates. The forest fire outbreaks by season shown in Table 3 indicate that forest fires broke out the most frequently in spring (46 cases, 73\%) followed by summer (11 cases, 17.5187\%), winter (6 cases, 9.5\%), and autumn ( 0 case, $0 \%$ ). Forest fires that occurred during the period of careful observation of spring forest fires (from 1 February to 15 May) and autumn forest fires (1 November to 15 December) are 51 cases, accounting for $81 \%$ of the total 63 cases. Here, it is considered that record of summer forest fires is left because of the specificity of forest fire outbreak caused by thunder stroke. Forest fires were also recorded in winter, December and January. 
Table 3. The number of fire in every month.

\begin{tabular}{ccccccccccccc}
\hline Month & Jan. & Feb. & Mar. & Apr. & May & Jun. & Jul. & Aug. & Sep. & Oct. & Nov. & Dec. \\
\hline Fires & 1 & 3 & 5 & 26 & 16 & 4 & 7 & - & - & - & - & 1 \\
\hline
\end{tabular}

\subsubsection{By Areas}

The distribution of forest fire outbreaks in the Joseon Dynasty period by area is as shown in Figure 4 . The largest number is shown in the east coast region (38 fires) followed by the west coast region ( 9 fires), Seoul and the central region ( 8 fires), the south coast region of Gyeongnam Province (8 fires), which indicates that about $60 \%$ of the forest fires were recorded to have occurred in the east coast region. In the case of Chungnam Province, two burnings for hunting were recorded. In the case of Seoul, four forest fires occurred in Mt. Namsan and one in Mt. Samgaksan, which is now Mt. Bukhansan, were recorded.

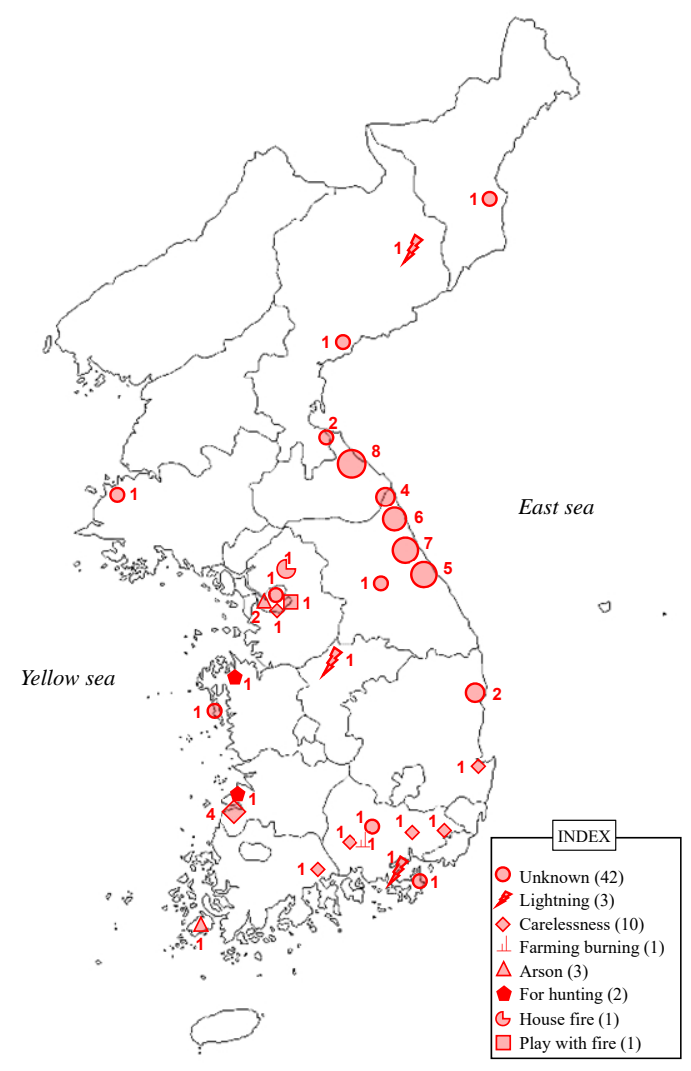

Figure 4. Distribution of forest fires in Joseon Dynasty.

\subsubsection{Forest Fire Damage}

The largest forest fire recorded in the historical records in the Joseon Dynasty period was shown to be the forest fire in the eastern coast of Gangwon Province, which occurred in the 4th year of King Sunjo's reign (1804). In this forest fire, not only 2600 private houses but also 3 lecture halls (院宇), 6 temples, 1 warehouse, about 4.8 ton of various grains, 12 vessels, and 27 salt ponds were burnt out and 61 deaths were recorded. At that time, King Sunjo recognized the seriousness of the forest fire damage and dispatched senior officer (Gyori, 校理) Hong Suk-Ju, as a royal secret inspector for the rescue of the victims along with the investigation of the damage. The forest fire that was recorded to have resulted in the greatest casualties occurred in the 13th year of King Hyeonjong's reign (1672) in the eastern coast in Gangwon Province with 65 deaths. In addition, in the 14th year of King Seongjong's reign (1489), the Yangyang forest fire caused damage to 205 private houses and Gwaneumjeon (觀音殿) 
in Naksansa temple, in the 19th year of King Jungjong's reign (1524), Gangneung forest fire caused damage to 244 private houses including Gangneung Daesan and the Gyeongpodae official residence, and in the 23rd year of King Sukjong's reign (1697), Gangneung forest fire burnt out 65 private houses under Mt. Daegwallyeong.

\subsection{Forest Fire Policies}

In particular, the seasonal classification of forest fire policy in the Joseon Dynasty was classified as the early days, the middle, and late Joseon Dynasty period. For this reason, the Gyeongguk Daejeon (經國大典), which became the foundation of the law systems of the Joseon Dynasty, was completed and enforced in 1476, and since then a new revised law (Sok Daejeon, 續大典) was enacted in 1746. In this study, it was classified into the early Joseon Dynasty (from a founding year to an enacted the Gyeongguk Daejeon, 1392-1476), the middle (from an enacted the Gyeongguk Daejeon to an enacted the Sok Daejeon) and the late period (from an enacted the Sok Daejeon to the fall, 1747-1910). According to the three period classification, it can be seen that 42 forest fires were recorded in the early days, 55 in the middle, and 11 in the late Joseon Dynasty period. On comparison of the numbers of cases of forest fire outbreak, as shown in Figure 5, it can be seen that the number of forest fire outbreaks was low in the early days of Joseon Dynasty period because of many forest fire prevention policies and that the number of forest fire outbreaks was large and the largest number of forest fire prevention policies were implemented in the middle of the Joseon Dynasty period.

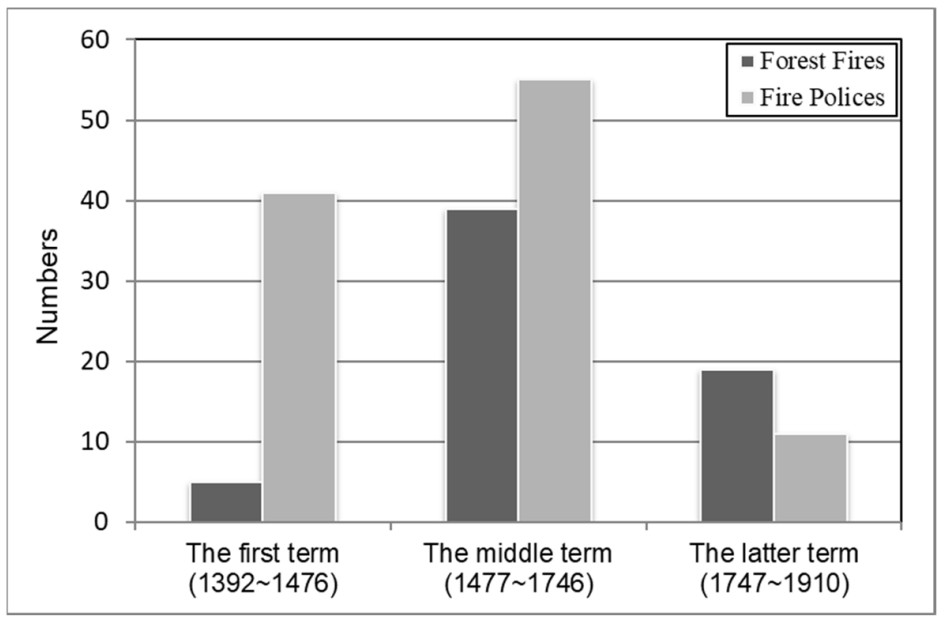

Figure 5. Comparison of forest fires and fire policies in each term.

\subsubsection{Type of Policy}

On reviewing the forest fire policies in the early days of the Joseon Dynasty period with a small number of forest fire outbreak records, it can be seen that, as shown in Table 4, 33 forest fire policies corresponding to about $78 \%$ of the total 42 forest fire policies, were implemented for forest fire prevention, and that the number of forest fire policies implemented in the early days of the Joseon Dynasty period was the largest at about 0.49 per year in the entire Joseon Dynasty period. In the middle of and late Joseon Dynasty period, the numbers of forest fire policies implemented were 0.2 /year and $0.07 /$ year, respectively. Forest fire policies were classified by area into those related to prevention, fire-fighting, restoration, punishment, defense, and livelihood stabilization. Four out of the 104 forest fire policies recorded in the historical books also contained policies to prohibit burning for hunting and slash-and-burn field cultivation recorded in the Annals of the Joseon Dynasty (朝鮮王朝實錄). Therefore, the number of policies was regarded to be 108. Among the policies, the number of those for prevention was shown to be the largest $(69,63.9 \%)$ followed by punishment $(18,16.7 \%)$, the stabilization of the people's livelihood $(8,7.4 \%)$, national defense $(5,5.6 \%)$, firefighting $(5,4.6 \%)$, and restoration $(2,1.9 \%)$ as shown in Figure 6. Here, the forest fire policies recorded in the fields of forest fire prevention 
are largely those for reinforcement of provincial government offices' forest fire related management, prohibiting the use of fire devices in the surroundings of forests, prohibiting burning for hunting, prohibiting burning for the cultivation of slash and burn fields, reduction of forest density through forest care, cooperation with Buddhist temples for prevention of forest fires, setting forest fires in areas where forest pest occurred to prevent the spread of pests, prohibition of entries or passage into forest areas and areas with risks of forest fires through major roads, and fire device management in the surroundings of royal tombs. The forest fire policies described in the fields of fire-fighting are those for the installation and use of forest fire extinguisher and the construction of firewalls to prevent the spread of forest fires and the forest fire policies described in the fields of restoration are those for the restoration of forest fire damage. In particular, the Health Forest project, which is a fuel reduction project to reduce the risk of forest fires currently implemented in Korea, was found to have been implemented in the 11th and 13th years of the reign of Sejong and in the 19th year of the reign of Injo in the records. In addition, the installation of fire-extinguishers in the field of fire-fighting was recorded in the 8th year of the reign of Sejong and the 19th year of the reign of Seongjong. However, no record is regarding the accurate form of the fire-extinguisher.

Table 4. Comparison with forest fires and fire policies in each term.

\begin{tabular}{|c|c|c|c|c|c|}
\hline \multicolumn{2}{|r|}{ Policy } & \multirow{2}{*}{$\begin{array}{l}\text { The First Term } \\
\text { (1392-1475) }\end{array}$} & \multirow{2}{*}{$\begin{array}{l}\text { The Middle Term } \\
\text { (1476-1746) }\end{array}$} & \multirow{2}{*}{$\begin{array}{l}\text { The Last Term } \\
(1747-1910)\end{array}$} & \multirow[b]{2}{*}{ Total } \\
\hline Total Type of Policy & Subject & & & & \\
\hline \multirow{10}{*}{ Prevention } & Fire management on local government & 3 & 2 & 3 & 8 \\
\hline & Prohibition of fire & 8 & 5 & - & 13 \\
\hline & Prohibition about fire for hunting & 8 & 6 & - & 14 \\
\hline & Prescribed burning & 6 & 11 & 1 & 18 \\
\hline & Decreasing forest density & 3 & 2 & - & 5 \\
\hline & Cooperation with Buddhist monk & 1 & - & - & 1 \\
\hline & The control of insect pests using fires & 1 & - & - & 1 \\
\hline & A reserved forest and way & - & 1 & - & 1 \\
\hline & Prevention in a royal tomb & 3 & 3 & 2 & 8 \\
\hline & Subtotal & 33 & 30 & 6 & 67 \\
\hline \multirow{3}{*}{ Suppression } & Disposition of fire suppression device & 1 & 1 & - & 3 \\
\hline & Installation of a fire wall & - & 2 & 1 & 2 \\
\hline & Subtotal & 1 & 3 & 1 & 5 \\
\hline Restoration & Restoration of damaged area & 1 & 1 & - & 2 \\
\hline Punishment & Execution, flogging, banishment & 2 & 15 & 1 & 18 \\
\hline National defense & Military operations & 5 & 1 & - & 6 \\
\hline Stabilization of livelihood & Relief & - & 5 & 3 & 8 \\
\hline Total & & 42 & 55 & 11 & 108 \\
\hline
\end{tabular}

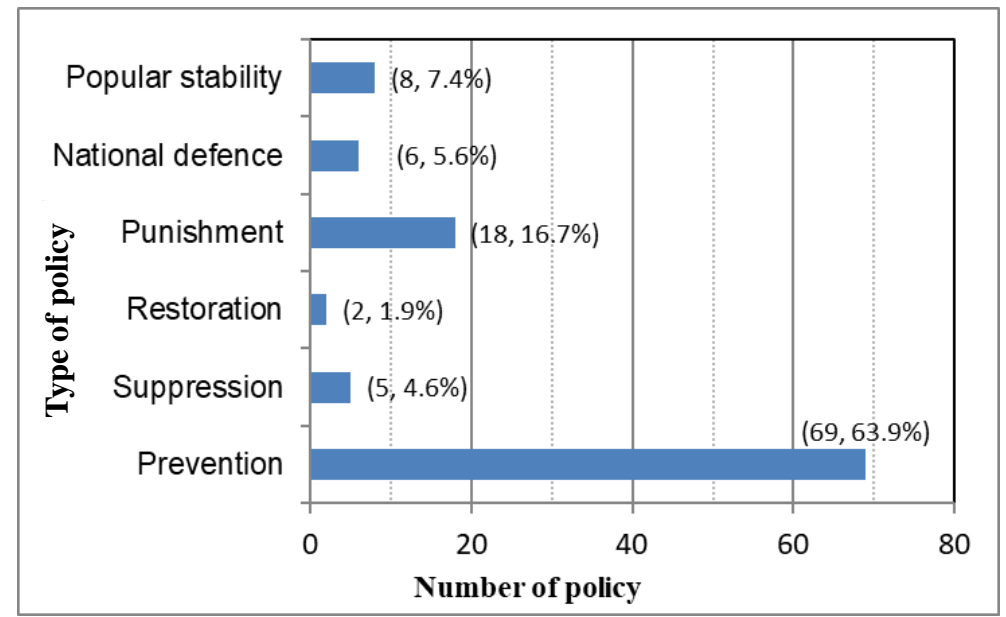

Figure 6. Policy for forest fires in Joseon Dynasty. 
As for penalties for the person who made a forest fire or the manager, first, severe penalties such as decapitation and hanging the cut head and status demotion are recorded for arsonists and in the case of those who made a fire by mistake, penalties less severe than those for arsonists such as banishment are recorded. In the case of penalties for the relevant government officer in the area where a forest fire broke out, reprimands such as dismissal are recorded while records that take warning against unreasonable penalties for management responsibility are also left. With regard to the use of forest fires for national defense, policies for clearing the field of fire for the military purpose of ensuring the visual field through incineration at the security area for national defense on the borderlines were found to have been implemented in the 19th, 23rd, and 29th years of the reign of Sejong, the 13th year of Sejo, and the 17th year of Seongjong. With regard to the protection of residents in areas damaged by forest fires, relief policies such as those to provide relief supplied to the stabilization of livelihood were found to have been carried out.

\subsubsection{Forest fire policies by period}

Forest fire policy period in the Joseon Dynasty is classified as early, middle and late shown in Table $4[27,36,37]$.

(1) Early days of the Joseon Dynasty period

- The forest fire policies in the early days of the Joseon Dynasty period for general forests demanded local bureaucrats to firsthand protect and control the forests, thereby awakening the awareness of local residents about the forest fires, and prohibited all acts of handling fire in general forests except for horse farms.

- As for the forest fire policies for reserved forests and prohibited forests, a law of the Ministry of National Defense titled 'a law of Ministry of National Defense regarding the cultivation of pine forests and conditions for the protection of military vessels' was promulgate to control the act of burning for the hunting and the cultivation of slash-and-burn fields in forests for military vessel materials as criminal acts. In addition, forest care and vegetation removal were carried out to protect royal tombs, royal ancestral shrines, and placenta chambers from forest fires and other fires.

- As for forest fire policies for martial art teaching fields (講武場, place for king's hunting and the military's martial art training), as forest fire damage increased even after the foundation of the Joseon Dynasty due to the hunting activities that had continued from the Goryeo Dynasty period, those who made a fire for hunting or the cultivation of slash-and-burn fields were punished by law.

- To console people in areas damaged by forest fires, royal secret inspectors were dispatched and relief policies were implemented, efforts were made to prevent forest fires at areas where forests were thick in each province, and the production of wild edible greens by burning was allowed in forests under poor conditions.

- With regard to the prevention of forest fire in archives or temples, along with the removal of the trees around the archives, preventive policies were implemented through the Buddhist monks.

- With regards to forest fire policies for the defense of the national territory such as those for beacon mounds, to prevent the diffusion of forest fires due to the carelessness of those who were lighting signal fire, $3.2 \mathrm{~m}$ wide, $3.2 \mathrm{~m}$ deep trenches were made to play the role of firebreak lines.

- Fires were made in damaged areas in some forests to control forest pest, rice paddy and field burning in the period in which insects appear from their holes in the earth by people to control pest was prohibited; provided that it was allowed in some limited areas such as those where horse farms are around rivers. 
(2) Middle of Joseon Dynasty period

- With regard to forest fire policies for general forest in the middle of the Joseon Dynasty period, as local bureaucrats set fire to the mountains for hunting, and people slashed and burn fields in the period of the reign of Sungjongdong, all of such acts were prohibited and the governors of individual provinces were instructed to prevent the act of making field fires and making fires for slash-and-burn fields in spring when the risk of forest fires was high.

- Fences were installed to protect the royal tombs, royal ancestral shrines, and placenta chambers from forest fires and other fires and the installation of ondol in ancestral rite rooms to prevent fires in royal ancestral shrines.

- Officials were appointed to stay around martial art teaching fields to plant broad-leaved trees, logging was prevented, and acts of handling fire were prohibited. In addition, forest fires were prevented in advance for the supply and demand of forest products.

- Royal secret inspectors were dispatched and relief policies were implemented to console people in areas damaged by forest fires, that is, supplies such as grains, cotton cloth, and hemp cloth were distributed in areas with damage by large forest fires for relief.

- With regard to prevention of forest fires in archives and temples, the archives that had been in town castles before the Japanese Invasion of Korea in 1592 were moved to deep into famous mountains for management and two Chambongs and 20-50 Buddhist monk soldiers were appointed to manage each archive.

- With regards to forest fire policies for the defense of the national territory such as those for beacon mounds, the act of making fires was prohibited to preserve the surrounding concealment forests.

(3) Late Joseon Dynasty period -Contents regarding the rewarding of provincial officials who managed forests well along with penalties for those who made fire in pine forests in reserved forests or prohibited forests were recorded in the 11th and 12th years of the reign of Jeongjo.

- With regard to forest fire policies for capital city forests, a policy to remove vegetation such as pine trees in a distance of $9 \mathrm{~m}$ (5 steps) outside from the castle wall and those in a distance of $18 \mathrm{~m}$ (10 steps) inside the castle wall was implemented in the 2nd year of the reign of Gojong.

- Along with the dispatch of royal secret inspectors for areas with forest fire damage, consoling officials were dispatched to areas suffered from large forest fires in the Yeongdong region in the period of the reign of Cheoljong.

- Forest fire policies for archives and temples can be identified from the firewall around the archive and Seonwonbogalk in the Odae Mountain archive firewall picture drawn by Danwon Kim Hongdo as shown in Figure 7. 


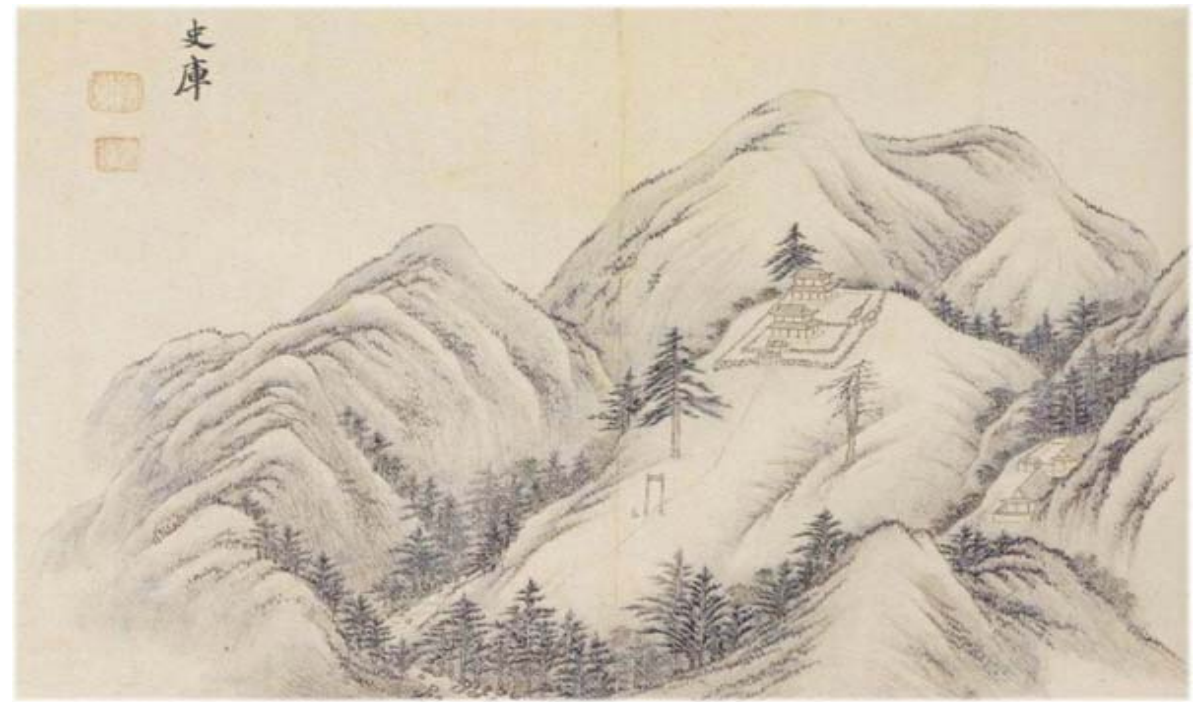

Figure 7. Archives in Mt. Odaesan (Hongdo Kim, 1778).

\section{Discussion}

In this study, forest fire records in the four pieces of literature, which are the Joseon Dynasty period historical records such 'the Annals of the Joseon Dynasty (朝鮮王朝實錄)', 'Seungjeongwon Ilgi, the Diaries of the Royal Secretariat (承政院日記)', 'Korean translation of Archives from Records of the Border Defense Council (國譯備邊司謄錄)', and 'the compilation of ministry proposals (各部聽議書存案)' were investigated. The main search words used in the record survey were words such as 'mountain fire (山火)', 'fire (火)', 'pine field (松田)', 'prohibited mountain (封山)', 'reserved mountain (禁山)', and 'arson (放火).' As a result, a total of 63 forest fire records were from the Joseon Dynasty period historical records. Since the 63 forest fire records include forest fire records by thunder stroke, ground fire, and spontaneous fires, which are hard to find in modern times, the fact that not only artificial fires but also forest fire outbreaks due to natural disasters, which were rare at that time, are included is unusual.

Also, through the forest fire outbreak records investigated this time, it can be seen that during the Joseon Dynasty period, pine trees were mainly used for construction of vessels including military ships and that the royal court made great effort to pine tree forests to the extent that managers were held responsible for cases of fire outbreak in pine fields, which are national resources, such as cutting the salary of related persons (provincial official, woodman) or dismissing them and penalizing them and investigating provincial officials. In particular, it can be seen that forest fires similar to the large-scale forest fire in the east coast of Gangwon Province, which occurred recently, occurred continuously during the Joseon Dynasty period too and the period of high risks of forest fire outbreaks at that time was also shown to be similar to that of now. Forest fires are most closely related to dry weather, and generally, when the PDSI (Palmer Drought Severity Index) is 0 or less, it can be said that it is dry and therefore, the chance of a forest fires is high. Thus, the PDSI data offered by the Monsoon Asia Drought Atlas was compared and examined. As a result, the average PDSI for 518 years of Joseon Dynasty was found to be 0.032 and -0.053 , and the PDSI at the eastern coast of Gangwon Province in 1672 and 1804, when the most severe damages by forest fires have been recorded in the history of forest fires, were investigated as -1.232 and 0.641 respectively [38]. Therefore, in 1672, the relation between drought and the danger of a forest fire can be described, but as for the year of 1804, because of the drought index was higher than the annual average PDSI and over 0 , which means a normal level, it has turned out to be inadequate to describe the correlation. These results seem to have been caused by the invalidity of the application of the danger of forest fires using the annual average of the drought index because storms and heavy rain are frequent in the summer owing to the Pacific air mass while it is especially dry and strong wind blows from February to May in the spring as the characteristics 
of Korean weather and climate. Thus, it has been concluded that it is reasonable to analyze with the PDSI value during February to May in the spring rather than with the correlation between the annual average of drought index and forest fire danger. Accordingly, the future research seems to need to analyze the contents on spring drought again and the interrelation between weather conditions and forest fires and to compare them with today's forest fires and tendency in weather conditions based on the hundreds of volumes of historical record during Joseon Dynasty.

The fact that the number of arson cases was large in Seoul, the capital city, compared to other regions was shown to be attributable to the fact that the population was dense in the capital area at that time too and a few people were dissatisfied with society. In this study, the analysis data for the time of forest fire outbreak include the forest fire without the record of accurate date of forest fire outbreak. Therefore, it is considered necessary to find the exact forest fire outbreak dates through investigation of related documents in the future.

\section{Conclusions}

Data were analyzed for agencies in charge of fires and forest fires, forest fire outbreak characteristics, and forest fire policies in the Joseon Dynasty period cantering on major national historical books such as the Annals of the Joseon Dynasty (朝鮮王朝實錄), Archives from Records of the Border Defense Council (備邊司謄錄), Seungjeongwon Ilgi, the Diaries of the Royal Secretariat (承政院日記) and the following conclusions were drawn.

(1) The forest management in the Joseon Dynasty period was under the charge of mountain and river officials in the Ministry of Industries among the six ministries to control businesses such as the production and use of forests.

(2) The forest fire management in the Joseon Dynasty period was conducted by mobilizing the central and local administrative organizations and the military organizations, and the forests in the entire country were divided into those around the capital city and the rest of the country for management. Forest fire management at the level of the central government was done by the Ministry of National Defense, which is a military organization, and the Ministry of Industries, an organization related to agriculture, forestry and fisheries and industry, and matters related to the royal family were managed by the Ministry of Culture and Education.

(3) The forest fire that caused the greatest casualties occurred in the 13th year of the reign of Hyeonjong (1672) of the east coast of Gangwon Province and 65 people died Another similar forest fire occurred in the 4th year of the reign of Sunjo (1804) in the same area leading to 61 deaths and the loss of 2600 private houses due to fire.

(4) As for forest fire outbreaks by season, spring showed the largest number of forest fire outbreaks (46 cases, 73\%) followed by summer (11 cases, $17.5 \%$ ), winter ( 6 cases, $9.5 \%$ ) and autumn $(0$ case, $0 \%)$ and the period in which forest fires occurred the most frequently in a year was shown to be April and May, identically to that of now. In the case of areas of high risks of forest fires outbreaks, the East Coast region showed the largest frequency (39 cases) followed by the West Sea Region (9 cases), Seoul/Central Region (8 cases), Gyeongnam South Coast region (8 cases), similarly to those of now.

(5) The causes of forest fire outbreaks were identified as unknown causes (42 cases) $>$ mistake (10 cases) $>$ arson, thunder stroke ( 3 cases each) $>$ burning for hunting ( 2 cases $)>$ child play with fire, rice paddy / field incineration, house fire (1 case each).

(6) The Joseon Dynasty period forest fire policies were largely divided into those for prevention, fire-fighting, restoration, punishing, national defense, and the stabilization of the people's livelihood. Among the total 108 forest fire policies, 63.9\% were implemented for prevention, $16.7 \%$ for punishment, $7.4 \%$ for the stabilization of the people's livelihood, $5.6 \%$ for national defense $4.6 \%$ for fire-fighting, and $1.9 \%$ for restoration. 
In conclusion, the historical records analysis shows that the risk and severity of forest fires are recorded in various documents and that the periods and areas of forest fire outbreaks are similar to the current Korean forest fire outbreak period and regional patterns. In the Joseon Dynasty period, diverse forest fire policies were implemented at the government level to suppress forest fire outbreak for the people's safety and improvement of national defense and national defense policies were implemented using forest fires.

Funding: This research received no external funding.

Conflicts of Interest: The authors declare no conflict of interest.

\section{References}

1. Korea Forest Service. 2017 Annual Report of Forestry Statics; Korea Forest Service: Daejeon, Korea, 2017; Volume 263.

2. Power, M.J.; Marlon, J.R.; Bartlein, P.J.; Harrison, S.P. Fire history and the Global Charcoal Database: A new tool for hypothesis testing and data exploration. Palaeogeogr. Palaeoclimatol. Palaeoecol. 2010, 291, 52-59. [CrossRef]

3. Anderson, R.S.; Starratt, S.; Jass, R.M.B.; Pinter, N. Fire and vegetation history on Santa Rosa Island, Channel Islands, and long-term environmental change in southern California. J. Quat. Sci. 2010, 25, 782-797. [CrossRef]

4. Gavin, D.G. Estimation of inbuilt age in radiocarbon ages of soil charcoal for fire history studies. Radiocarbon 2001, 43, 27-44. [CrossRef]

5. Huang, C.C.; Pang, J.; Chen, S.E.; Su, H.; Han, J.; Cao, Y.; Tan, Z. Charcoal records of fire history in the Holocene loess-soil sequences over the southern Loess Plateau of China. Palaeogeogr. Palaeoclimatol. Palaeoecol. 2006, 239, 28-44. [CrossRef]

6. Millspaugh, S.H.; Whitlock, C.; Bartlein, P.J. Variations in fire frequency and climate over the past $17,000 \mathrm{yr}$ in central Yellowstone National Park. Geology 2000, 28, 211-214. [CrossRef]

7. Hessl, A.E.; Brown, P.; Byambasuren, O.; Cockrell, S.; Leland, C.; Cook, E.; Suran, B. Fire and climate in Mongolia (1532-2010 Common Era). Geophys. Res. Lett. 2016, 43, 6519-6527. [CrossRef]

8. Yao, Q.; Brown, P. M.; Liu, S.; Rocca, M. E.; Trouet, V.; Zheng, B.; Wang, X. Pacific-Atlantic Ocean influence on wildfires in northeast China (1774 to 2010). Geophys. Res. Lett. 2017, 44, 1025-1033. [CrossRef]

9. Bond, W.J. Fire and Plants. In Population and Community Biology Series 14; Bond, W.J., Van Wilgen, B.W., Eds.; Chapman \& Hall: London, UK, 1996; Volume 263.

10. Scott, A.C. The Pre-Quaternary history of fire. Palaeogeogr. Palaeoclimatol. Palaeoecol. 2000, 164, 281-329. [CrossRef]

11. Westerling, A.L.; Hidalgo, H.G.; Cayan, D.R.; Swetnam, T.W. Warming and earlier spring increase western US forest wildfire activity. Science 2006, 313, 940-943. [CrossRef] [PubMed]

12. Power, M.J.; Whitlock, C.; Bartlein, P.; Stevens, L.R. Fire and vegetation history during the last 3800 years in northwestern Montana. Geomorphology 2006, 75, 420-436. [CrossRef]

13. Gavin, D.G.; Hallett, D.J.; Hu, F.S.; Lertzman, K.P.; Prichard, S.J.; Brown, K.J.; Lynch, J.A.; Bartlein, P.; Peterson, D.L. Forest fire and climate change in western North America: Insights from sediment charcoal records. Front. Ecol. Environ. 2007, 5, 499-506. [CrossRef]

14. Bowman, D.M.; Balch, J.K.; Artaxo, P.; Bond, W.J.; Carlson, J.M.; Cochrane, M.A.; D’Antonio, C.M.; DeFries, R.S.; Doyle, J.C.; Harrison, S.P.; et al. Fire in the Earth system. Science 2009, 324, 481-484. [CrossRef]

15. Hardiman, M.; Scott, A.C.; Pinter, N.; Anderson, R.S.; Ejarque, A.; Carter-Champion, A.; Staff, R.A. Fire history on the California Channel Islands spanning human arrival in the Americas. Phil. Trans. R. Soc. B 2006, 371, 20150167. [CrossRef] [PubMed]

16. The Global Paleofire Working Group (GPWG). Available online: https:/ /www.gpwg.paleofire.org/ (accessed on 18 December 2018).

17. Lim, C.H.; Kim, S.H.; Choi, Y.; Kafatos, M.C.; Lee, W.K. Estimation of the Virtual Water Content of Main Crops on the Korean Peninsula Using Multiple Regional Climate Models and Evapotranspiration Methods. Sustainability 2017, 9, 1172. [CrossRef]

18. Lim, C.H.; Yoo, S.; Choi, Y.; Jeon, S.W.; Son, Y.; Lee, W.K. Assessing Climate Change Impact on Forest Habitat Suitability and Diversity in the Korean Peninsula. Forests 2018, 9, 259. [CrossRef] 
19. Lamchin, M.; Lee, W.K.; Jeon, S.W.; Wang, S.W.; Lim, C.H.; Song, C.; Sung, M. Long-term trend and correlation between vegetation greenness and climate variables in Asia based on satellite data. Sci. Total Environ. 2018, 618, 1089-1095. [CrossRef] [PubMed]

20. Yi, S.; Kim, S.J. Vegetation changes in western central region of Korean Peninsula during the last glacial (ca. 21.1-26.1 cal kyr BP). Geosci. J. 2010, 14, 1-10. [CrossRef]

21. Annals of Joseon Dynasty (朝鮮王朝實錄, Since 472 Years), Volume 1-28. Available online: http: / / silok.history. go.kr/ (accessed on 1 September 2018).

22. Annals of King Choljong (哲宗實錄), Volume 15. Available online: http:/ / silok.history.go.kr/ (accessed on 1 September 2018).

23. The Korean History Research Association. Sugyojiprok (受教集錄); Translated and Annotated ver.; $2001 ;$ p. 366. Available online: http:/ / db.history.go.kr/ (accessed on 4 January 2019).

24. The Korean History Research Association. Sinbosugyijiprok (新補受教集錄); Translated and Annotated ver.; 1967; p. 576. Available online: http:/ / db.history.go.kr/ (accessed on 4 January 2019).

25. The Academy of Korean Studies. GeumjoJeolmokleemoon (禁條節目移文); Translated and Annotated ver. 2004 Available online: http:/ /yoksa.aks.ac.kr/ (accessed on 4 January 2019).

26. Institute for Korean Studies Collection. Archives from Records of the Border Defense Counsil (備邊司謄錄); Translated and Annotated ver.; 2012; Volumes 1-10. Available online: http:/ / db.history.go.kr/ (accessed on 4 January 2019).

27. Yoon, K.I. Gyeonggukdaejeon (經國大典); Translated and Annotated ver.; 2001; Volume 6. Available online: http:/ / db.history.go.kr/ (accessed on 4 January 2019).

28. Institute for Translation of Korea Classics. Essentials of Goryeo History (高麗史節要); Translated and Annotated ver.; 1976; Volumes 1-5. Available online: http:/ / db.history.go.kr/ (accessed on 4 January 2019).

29. National Institute of Korean History. Jenungbomunheonbigo (增補文獻備考); Translated and Annotated ver.; 2012; Volumes 1-250. Available online: http:/ / db.history.go.kr/ (accessed on 4 January 2019).

30. Korea Legislation Research Institute. Daejeonhoetong (大典會通); Translated and Annotated ver.; 2002. Available online: http:/ / db.history.go.kr/ (accessed on 4 January 2019).

31. Korea Ministry of Government Legislation. Daejonsoklok (大典續錄); Translated and Annotated ver.; 1975; p. 294. Available online: http:/ / db.history.go.kr/ (accessed on 4 January 2019).

32. National Institute of Korean History. The Daily Records of Royal Secretariat of Joseon Dynasty (承政院日記), 2012, Volumes 1-351. Available online: http:/ / db.history.go.kr/ (accessed on 1 September 2018).

33. The Korean History Research Association. The Compilation of Ministry Proposals (各部聽議書存案); Translated and Annotated ver.; 1899. Available online: http: / silok.history.go.kr/ (accessed on 1 September 2018)

34. Bae, J.S. The Forest Policy in the Late Joseon Dynasty Korea Forest Research Institute; Bae, J.S., Kim, S.K., Lee, K.B., Joo, R.W., Eds.; Korea Forestry Promotion Institute: Seoul, Korea, 2002; pp. 204-219. Available online: http:/ / know.nifos.go.kr/book/search/DetailView.ax?cid=123242 (accessed on 4 January 2019).

35. Cha, S. Joseon Dynasty History of a Foreign Country (朝鮮史外史); 1947. Available online: http:/ / silok.history. go.kr/ (accessed on 4 January 2019).

36. Kim, M.J. Study on the Mountains Management of the Capital City in the Former Joseon Dynasty. Keimyung Korean Stud. J. 2010, 40, 453-485. Available online: http:/ / www.dbpia.co.kr/Journal/ArticleDetail/ NODE01468633 (accessed on 4 January 2019).

37. Kim, M.J. A Study of Tree Planting Activities in the Later Joseon Dynasty. Keimyung Korean Stud. J. 2011, 43, 249-282. Available online: http:/ / www.dbpia.co.kr/Journal/ArticleDetail/NODE01653765 (accessed on 4 January 2019).

38. The Monsoon Asia Drought Atlas. Available online: http://drought.memphis.edu/MADA/ (accessed on 1 September 2018).

(C) 2019 by the author. Licensee MDPI, Basel, Switzerland. This article is an open access article distributed under the terms and conditions of the Creative Commons Attribution (CC BY) license (http:/ / creativecommons.org/licenses/by/4.0/). 